\title{
Functionalization of Glycals Leading to 2-Deoxy-O-glycosides, Aminosugars, Nitrosugars and Glycosidase Inhibitors: Our Experience
}

\author{
Rima Lahiri, Suresh Dharuman, and Yashwant D. Vankar*
}

\begin{abstract}
Glycals have been transformed into a variety of functionalized substrates which have been found to be useful in synthesizing some aminosugars, N-glycopeptides, nitrosugars and some iminosugars which are potential glycosidase inhibitors. An account of work that has been done in our laboratory is briefly discussed here.
\end{abstract}

Keywords: Aminosugars · Azidosugars · 2-Deoxy-O-glycosides · Glycals · N-Glycopeptides · Glycosidase inhibitors · Nitrosugars

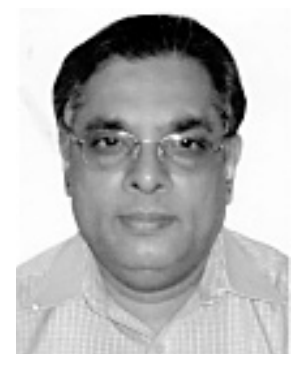

Yashwant

D.

Vankar was born in 1950 at Varanasi, India. He obtained his M.Sc. (organic chemistry) degree from the Banaras Hindu University, Varanasi in 1971. Further, he obtained his Ph.D. degree by working at the National Chemical Laboratory, Pune, India under the guidance of Professor B. D. Tilak. He then worked as a postdoctoral fellow at the King's College, London (with Professor David I. Davies, 1976-1977), at the University of Southern California, Los Angeles (with Professor George A. Olah, Nobel Laureate, 19771979) and then at the Rice University, Houston (with Professor Ernest Wenkert, 1979-1980). After returning to India, he joined the Chemistry Department at the Indian Institute of Technology Kanpur as a Lecturer in 1981, and since 1991 he has been a full professor at the same institute. He also spent a year (1990-1991) as an Alexander von Humboldt fellow at the Universität Konstanz (Germany, with Professor Richard R. Schmidt). His major research interests are different aspects of synthetic organic chemistry with special emphasis on carbohydrate chemistry of biological importance and development of newer methodologies.

${ }^{*}$ Correspondence: Prof. Y. D. Vankar Department of Chemistry Indian Institute of Technology Kanpur Kanpur 208016, India

E-mail: vankar@iitk.ac.in

\section{Introduction}

Glycals are important synthons ${ }^{[1]}$ in organic chemistry. The enol ether moiety in glycals is susceptible to electrophilic attack at $\mathrm{C}(2)$ (Scheme 1) to form an oxonium ion 'A' that will trap a nucleophile 'Nu' to generate a species of kind ' $\mathrm{B}$ '. The usefulness of product ' $\mathrm{B}$ ' depends on the nature of the electrophile ('E') and the nucleophile ' $\mathrm{Nu}$ '. For example, O-, C-, and N-glycosides will clearly be formed by reaction with O-, C-, and N-derived nucleophiles. Several different types of reactions have already been reported in the literature ${ }^{[2]}$ related to the reactions of glycals and they have been employed in carbohydrate chemistry, ${ }^{[3]}$ as well as in natural product synthesis. ${ }^{[4]}$ In our pursuit of functionalizing glycals we have developed various methodologies and applied them in the formation of 2-deoxy$O$-glycosides, aminosugars, nitrosugars, $\mathrm{N}$-glycopeptides and some glycosidase inhibitors. In this mini review we present our results of these endeavors.

\section{Ceric Ammonium Nitrate Catal- yzed Synthesis of 2-Deoxy-1-O- glycosides}

Several years ago, we studied the reaction of alkenes with $\mathrm{NaNO}_{2} /$ ceric ammonium nitrate (CAN) in acetonitrile and reported ${ }^{[5]}$ that such a combination leads to the formation of the corresponding vicinal nitroacetamides 1 (Scheme 2). It was proposed that the reaction proceeds via a mechanism as shown in Scheme 2. Assuming the importance of 1,2-diamines in carbohydrate chemistry we decided to

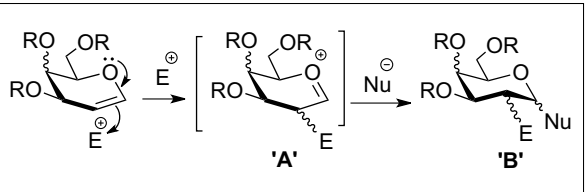

Scheme 1.

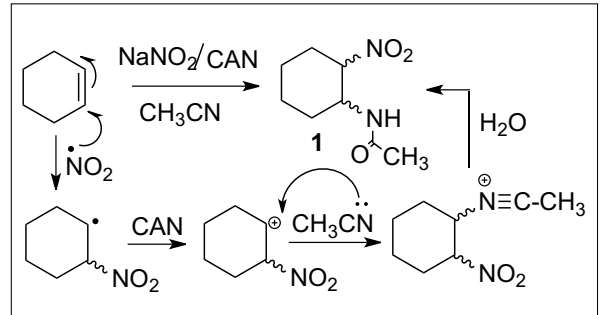

Scheme 2.

explore the reactivity of such a reagent system with glycals hoping to form 2-nitro-1-acetamide-derived sugar derivatives which could be useful to provide access to 2-deoxy- $N$-glycopeptides and 2-amino- $N$ glycopeptides. ${ }^{[6]}$ With this view in mind, when 3,4-dihydro-2-H-pyran, as a model example, was treated with $\mathrm{NaNO}_{2} / \mathrm{CAN} /$ $\mathrm{CH}_{3} \mathrm{CN}$, no expected nitro acetamide was formed and the reaction led to a mixture from which no worthwhile product could be identified. However, when, in order to study the solvent effect, methanol was used as a solvent, surprisingly, the corresponding tetrahydropyranyl ether was formed. Re-examination of the reaction conditions led us to use only catalytic amounts of CAN and two equivalents of dihydropyran and in this way a number of alcohols gave the corresponding THP ethers in good to excellent yields. A few examples are shown in Fig. 1. Application of this methodology 


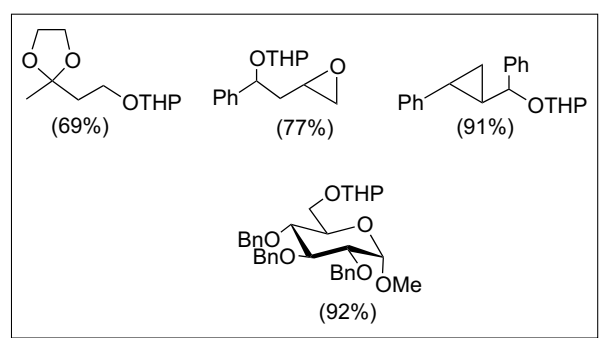

Fig. 1.

to glycals gave the corresponding 2-deoxy1 - $O$-glycosides with $\alpha$-anomeric selectivity. ${ }^{[7]}$ Galactal derivatives were found to undergo glycosidation using only $2 \mathrm{~mol} \%$ of CAN, with good to excellent selectivity, though a small amount of the corresponding Ferrier product ${ }^{[8]}$ was formed in some cases. Surprisingly, however, Ferrier products were formed as the major products with glucal derivatives using $2 \mathrm{~mol} \%$ of the CAN. On the other hand, usage of four equivalents of CAN suppressed the formation of the Ferrier products to some extent and moderate yields of the $\alpha$-glycosides were obtained in some cases. Thus, it is clear that the present method is more useful for making THP ethers and also 2deoxy-1-O-galactosides. A few examples along with yields and selectivity are shown in Fig. 2.

A tentative mechanism for this reaction is shown in Scheme 3 that involves the

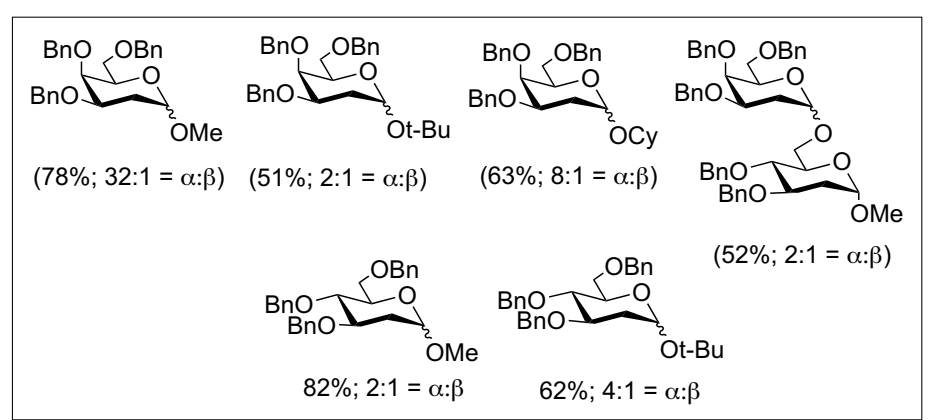

Fig. 2.

formation of $\mathrm{HNO}_{3}$ and alcohol-containing ceric ammonium nitrate that transfers the alcohol and completes the glycosidation (path A). Alternatively, the reaction may also proceed via an electron transfer process (path B, Scheme 3).

Even though we were not able procure the 1,2-diamino sugar derivatives, this conversion of glycals to 2-deoxy- $O$-glycosides could be useful as there are several natural products that contain 2-deoxy sugars such as aureolic acid, ${ }^{9]}$ compactin, ${ }^{[10]}$ calicheamicin, ${ }^{[11]}$ etc.

\section{3. $\mathrm{Me}_{3} \mathrm{SiN}_{3}-\mathrm{Me}_{3} \mathrm{SiONO}_{2}$-mediated Synthesis of 1-Azido-2-deoxy Sugars}

In continuation of our attempts to functionalize glycals to obtain 1,2-diamino sugars, we expected that a combination of

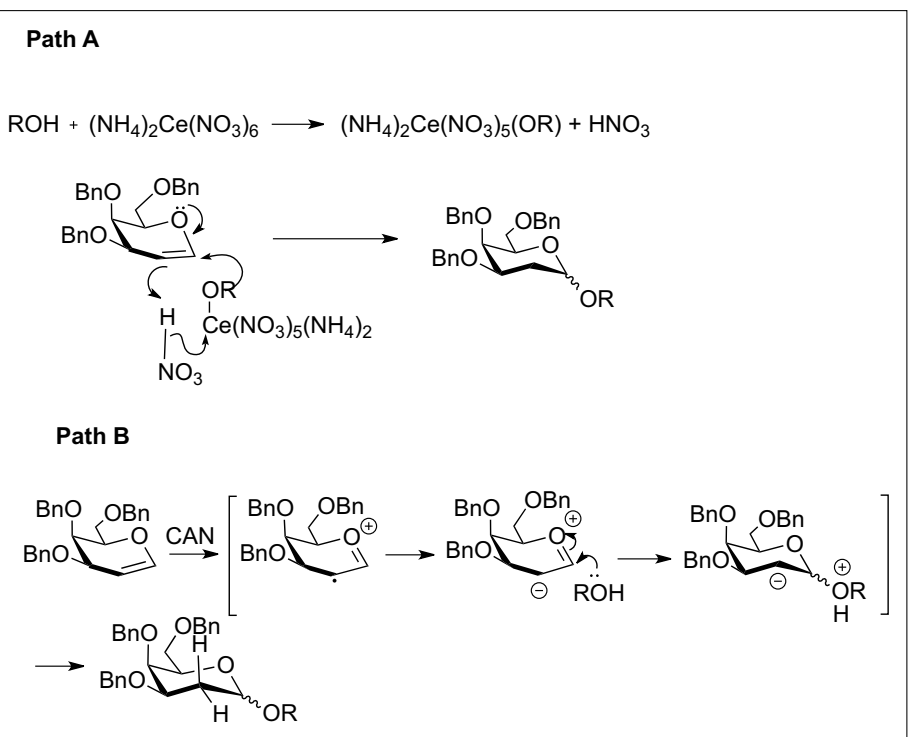

Scheme 3.

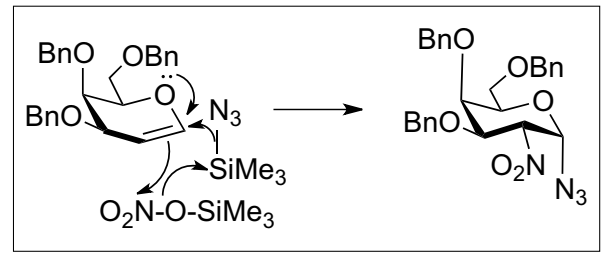

Scheme 4.

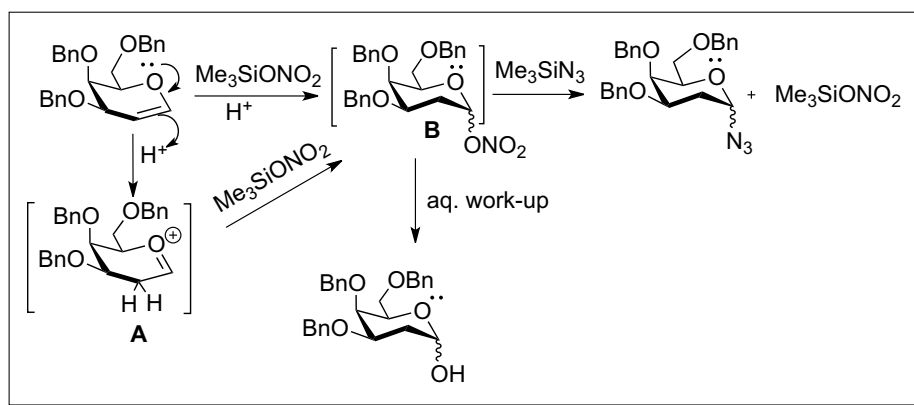

$\mathrm{Me}_{3} \mathrm{SiN}_{3}$ and $\mathrm{Me}_{3} \mathrm{SiONO}_{2}$ should lead to 1-azido-2-nitro sugars as shown in Scheme 4. This was presumed because a similar combination of $\mathrm{Me}_{3} \mathrm{SiONO}_{2}$ and $\mathrm{CrO}_{3}$ had led ${ }^{[12]}$ to the conversion of olefins to $\alpha$-nitro ketones in one step. It was expected that the nitro group at $\mathrm{C}(2)$ could be either reductively removed to form 1-azido-2-deoxy sugars, or the nitro group reduced to an amino functionality to form 2-amino1-azido sugars eventually leading to 2 -deoxy-1- $\mathrm{N}$-glycopeptides and 2-amino- $1-\mathrm{N}$ glycopeptides respectively. With this view in mind, $\mathrm{Me}_{3} \mathrm{SiONO}_{2}$ was prepared by reacting $\mathrm{ClSiMe}_{3}$ and $\mathrm{AgNO}_{3}$ in acetonitrile followed by filtering off the precipitated $\mathrm{AgCl}$. Interestingly, a combination of such a solution of $\mathrm{Me}_{3} \mathrm{SiONO}_{2}$ and $\mathrm{Me}_{3} \mathrm{SiN}_{3}$ when reacted with glycals anticipating the formation of 1-azido-2-nitro sugars led to the formation of 2-deoxy-1-azido sugars. Clearly, the $\mathrm{Me}_{3} \mathrm{SiONO}_{2}$ species appeared to have no role in the process, but $\mathrm{Me}_{3} \mathrm{SiN}_{3}$ alone, obviously, cannot convert glycals to 2-deoxy-1-azido sugars. We anticipated that a proton source must be emanating from $\mathrm{ClSiMe}_{3}$ which was not specifically treated to remove contaminated $\mathrm{HCl}$. We further assumed that this particular reaction may be proceeding as shown in Scheme 5 .

Later, we also noticed that $20 \mathrm{~mol} \%$ of $\mathrm{Me}_{3} \mathrm{SiONO}_{2}$, taken from the bulk acetonitrile solution, also gave the desired 1-azido-2-deoxy sugars suggesting that $\mathrm{Me}_{3} \mathrm{SiONO}_{2}$ is required in catalytic amount as per the above shown mechanism. However, it is clear that the $\mathrm{H}^{+}$ should be present in sufficient amounts so that the protonation occurs on a molar basis to permit the formation of the oxonium ion 'A' (Scheme 5). Further, it was proved by mass spectrometry that the formation of intermediate nitrate ester 'B' indeed

A 


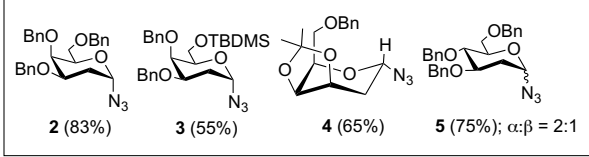

Fig. 3.

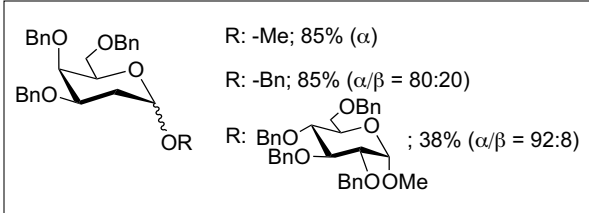

Fig. 4.

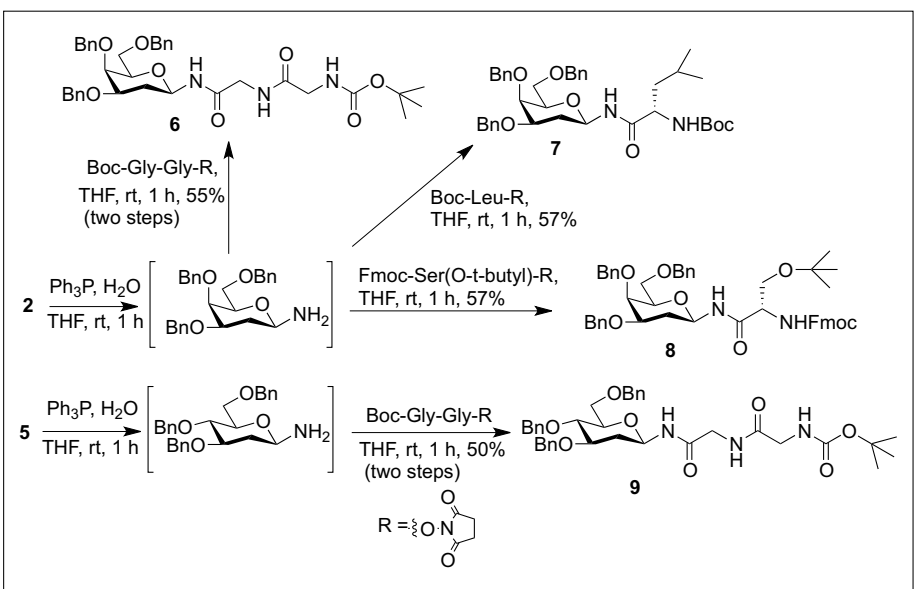

Scheme 6.

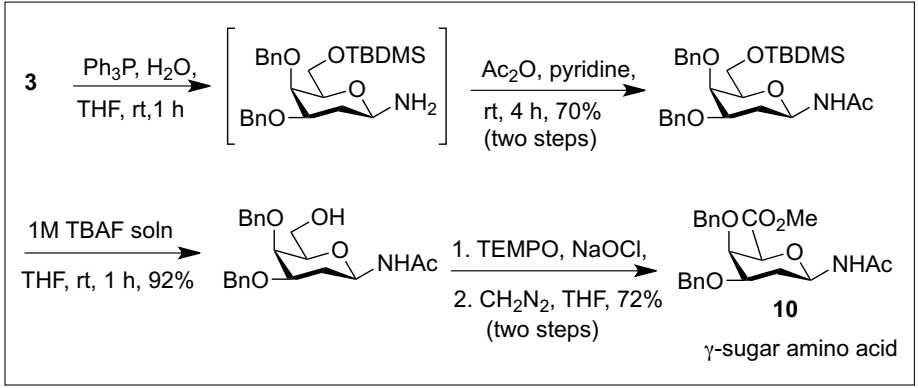

Scheme 7.

occurs as the first step but since it is relatively unstable on column chromatography it could not be isolated in pure form. Since preformed $\mathrm{HN}_{3}$ did not add on to the glycals, our procedure of indirect addition of $\mathrm{HN}_{3}$ to glycals using $\mathrm{Me}_{3} \mathrm{SiONO}_{2} / \mathrm{M}_{3} \mathrm{SiN}_{3}$ combinations is a useful procedure ${ }^{[13]}$ to convert glycals to 1-azido-2-deoxy sugars which are normally prepared by displacing a leaving group such as an acetate, mesylate or a halide [14] at the anomeric carbon by an azide group. A few representative examples of the 1-azido-2-deoxy sugars are shown in Fig. 3.

The azide group at the anomeric carbon could be readily reduced with $\mathrm{Ph}_{3} \mathrm{P}$ and water $^{[15]}$ and condensed the corresponding amine with several amino acids to form the corresponding 2-deoxy-1- $N$-glycopeptides as shown in Scheme 6. Likewise, one of the azido sugars viz. 3 was converted into a $\gamma$-sugar amino acid $\mathbf{1 0}$, as shown in Scheme 7.

\section{4. $\mathrm{Me}_{3} \mathrm{SiONO}_{2}$-catalyzed Synthesis of 2-Deoxy-1-O-glycosides}

An obvious extension of the $\mathrm{Me}_{3} \mathrm{SiONO}_{2}$-mediated conversion of glycals into 1-azido-2-deoxy sugars is to examine the outcome of the reaction by replacing $\mathrm{Me}_{3} \mathrm{SiN}_{3}$ by alcohols anticipating the formation of 2-deoxy-1-O-glycosides. Indeed it was the case and a variety of alcohols underwent reaction with 2,4,6-tri- $O$ benzyl galactal to form the corresponding 2-deoxy- $O$-glycosides in good yields with high or exclusive $\alpha$-anomeric selectivity. ${ }^{[16]}$ As expected, 2,4,6-tri- $O$-benzyl glucal upon reaction with methanol gave a mixture of 2-deoxy- $O$-glycosides and the corresponding Ferrier product in 70:30 ratio wherein the $\alpha / \beta$ ratio of the 2-deoxy- $O$ glycoside was 55:45 and that of the Ferrier product was 90:10. We, however, carried out our studies with 2,4,6-tri-O-benzyl galactal as it did not give any Ferrier product. The reaction required one equivalent of $\mathrm{Me}_{3} \mathrm{SiONO}_{2}$ for successful completion of the reaction. It is clear that the reaction proceeds via the formation of 2-deoxy1-nitrate ester which further reacts with alcohols to replace the nitrate ester with the alcohol forming 2-deoxy-1-O-glycosides. The proposed mechanism is shown in Scheme 8. Since the reaction proceeds via an oxonium ion, the anomeric effect operates and the $\alpha$-selectivity is high. A few representative examples are shown in Fig. 4.

\section{Synthesis of 2-lodo-1-azido Sugars and Methyl N-Acetyl- $\alpha-D-$ lividosaminide}

We further found[17] that a combination of oxone, KI and $\mathrm{NaN}_{3}$ on alumina (or that of $\mathrm{N}$-iodosuccinimide and $\mathrm{NaN}_{3}$ ) led to a clean formation of 2-iodo-1-azido sugars from glycals with excellent stereoselectivity in most of the cases studied, with dominance of 1,2-diaxial orientation

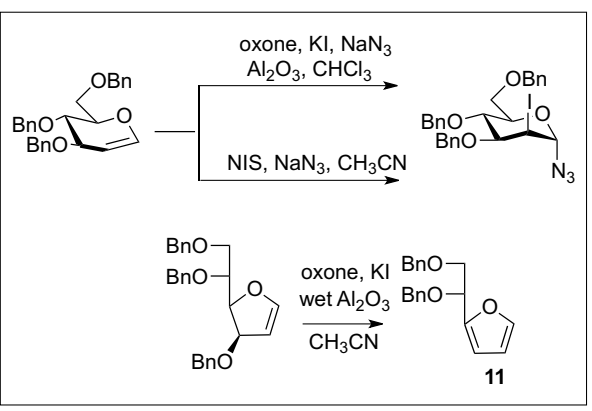

Scheme 9 .

of iodide and the azide moieties. The reaction with pyranoglycals were equally facile with both the reagent systems. However, furanoglycals reacted only with the NIS/ $\mathrm{NaN}_{3}$ reagent system leading to the desired 2-iodo-1-azido furanose sugars, but with the oxone-derived reagent system formation of a furan derivative 11 (Scheme 9) was observed, which is an important intermediate in organic synthesis. ${ }^{[18]}$ Also, 6-O-trityl- and 6-O-TBDMS-protected pyranoglycals reacted smoothly with NIS/ $\mathrm{NaN}_{3}$ to form the 2-iodo-1-azido sugars in excellent yields. The same reactions, however, were not clean with an oxone-derived reagent system. The stereoselectivity of the reaction was found to drop down when the reactions were carried out with 3-deoxy glycals. Thus, 3-deoxy-4,6-di- $O$-benzyl glucal gave $5.5: 1$ ratio of the $\alpha / \beta$-anomeric products, whereas 3-deoxy-4,6-di- $O$ acetyl glucal gave a 2:1 ratio of the $\alpha / \beta$ anomeric iodoazides 12 , from which the $\alpha$-isomer was then converted into methyl $N$-acetyl- $\alpha$-D-lividosaminide $\mathbf{1 3}$ as shown in Scheme 10. We have also earlier reported ${ }^{[19]}$ the formation of this important amino sugar which is an integral part aminoglycoside antibiotics lividomycin A and B isolated from Streptonyces lividus, and 3'-deoxy kanamycin $\mathrm{C}$, isolated from a mutant 


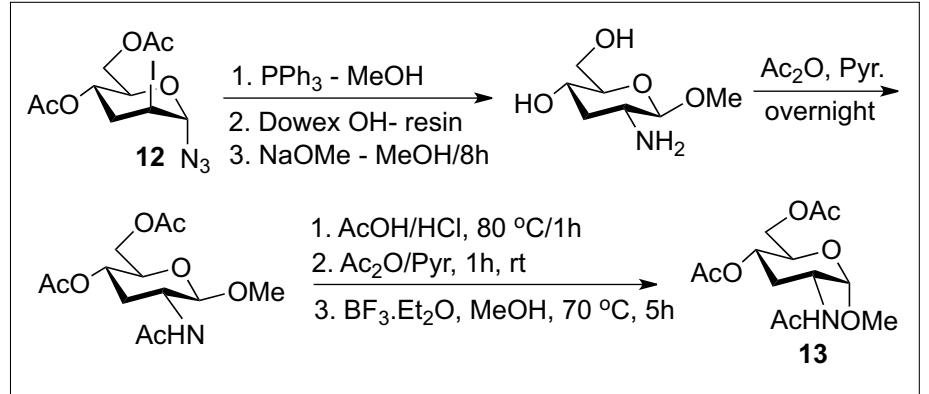

Scheme 10.

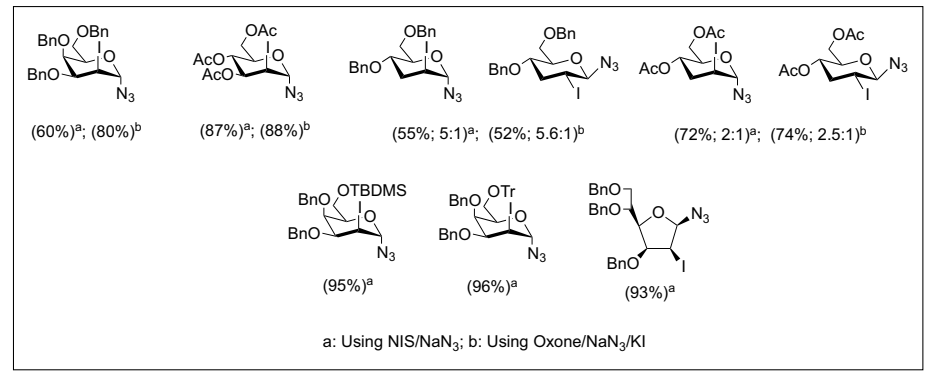

Fig. 5

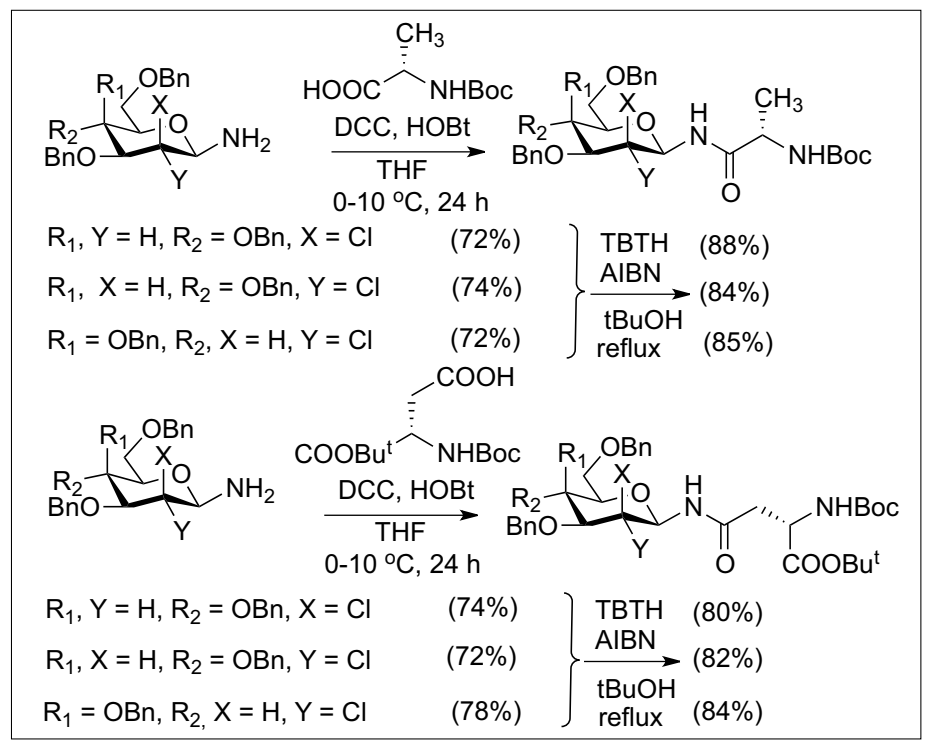

Scheme 14.

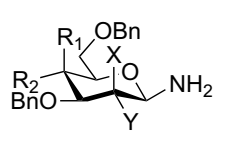

$\begin{array}{lc}\text { IC-50 values against } & \text { IC-50 Values against } \\ \text { U-87 Malignant Glyoma } & \text { Normal Hek Cell Lines } \\ \text { Cell Lines } & (100 \mu \mathrm{M})) \\ (0.001 \mu \mathrm{M}) & 37 \mu \mathrm{M})) \\ (0.1 \mu \mathrm{M}) & (>100 \mu \mathrm{M})) \\ (0.04 \mu \mathrm{M}) & \end{array}$

$\begin{array}{lc}\begin{array}{l}\text { IC-50 values against } \\ \text { U-87 Malignant Glyoma } \\ \text { Cell Lines }\end{array} & \begin{array}{c}\text { IC-50 Values against } \\ \text { Normal Hek Cell Lines }\end{array} \\ (0.001 \mu \mathrm{M}) & (100 \mu \mathrm{M})) \\ (0.1 \mu \mathrm{M}) & 37 \mu \mathrm{M})) \\ (0.04 \mu \mathrm{M}) & (>100 \mu \mathrm{M}))\end{array}$

Fig. 6.

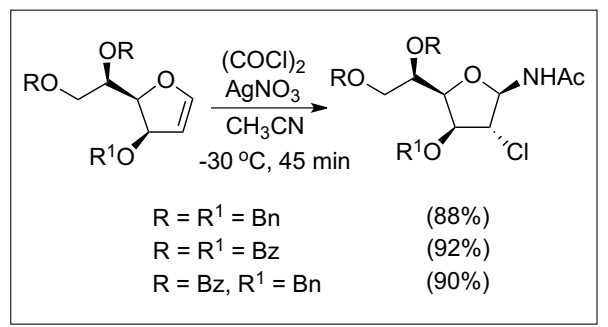

Scheme 13. (39\%) $\quad(41 \%)$ $\begin{array}{ccc}- & (41 \%) & (43 \%) \\ (75 \%) & - & (5 \%) \\ (80 \%) & - & (5 \%)\end{array}$
Scheme 12.

\section{Scheme 13.}

of Streptomyces cremeus tobramycin. ${ }^{[20]}$ A few examples of the iodoazides are shown in Fig. 5. Further, it is also interesting to note that while pyranoglycals gave 1,2-trans-2-deoxy-2-iodoglycosyl azides, the furanoglycals gave exclusively the 1,2-cis-2-deoxy-2-iodoglycosyl azides.

\section{Oxalyl Chloride-AgNO $-\mathrm{CH}_{3} \mathrm{CN}-$ mediated Synthesis of 2-Chloro-1- acetamido Sugars}

Further, in our quest of discovering a reagent system that could convert glycals into a course of 1,2-diamino sugars we considered that a new reagent system comprising oxalyl chloride, $\mathrm{AgNO}_{3}$ in acetonitrile to form 2-nitro-acetamido sugars. This was anticipated considering that an intermediate of type 'A' (Scheme 11) will result, along with precipitation of $\mathrm{AgCl}$, and it would act as a source of nitronium ion thus enabling glycals to form 2-nitro1-acetamido sugars as shown in Scheme 11 (Path 'A'). However, such a reagent system turned out to be a source of chloronium ion allowing glycals into 2-chloro-1-acetamido sugars (Path 'B', Scheme 11). Both pyrano galactal as well as pyrano glucal derivatives gave 2-chloro-1-acetamido sugars in varied ratios as shown in Scheme 12. However, furanoglycals gave exclusively one stereoisomer as shown in Scheme 13. [21]

Although glucal derivatives gave a mixture of two diasteromers in almost equal ratio, it was generally observed that galctal derivatives showed better stereoselectivity. It was possible to develop reaction conditions to efficiently deprotect the chloroacetamides using $0.7 \mathrm{~N} \mathrm{HCl}$

in $\mathrm{MeOH}$ at $55^{\circ} \mathrm{C}$. The glycosyl amines were then coupled with suitably protected amino acids using DCC and HOBt in THF and the corresponding 2-chloro- $\beta$ $\mathrm{N}$-glycopeptides were obtained in good yields. A few representative glycopeptides are shown in Scheme 14.

Glycal-derived 2-deoxy-sulfonamides were reported to be potent inhibitors for the growth of heptacellular carcinoma cell lines by Colinas et al. ${ }^{[22]}$ In view of this we became interested to examine the cytotoxic behavior of some of the sugar-derived chloroacetamides and the corresponding glycosyl amines. Our results showed that the IC-50 values against U-87 Malignant Glyoma (brain tumor) are in the range 1 $\mathrm{nM}$ to $37 \mu \mathrm{M}$, whereas the corresponding IC-50 values against Human Embryonic Kidney (normal) cell lines ranged from 37 $\mu \mathrm{M}$ to more than $100 \mu \mathrm{M}$. A few representative examples are shown in Fig. 6. 


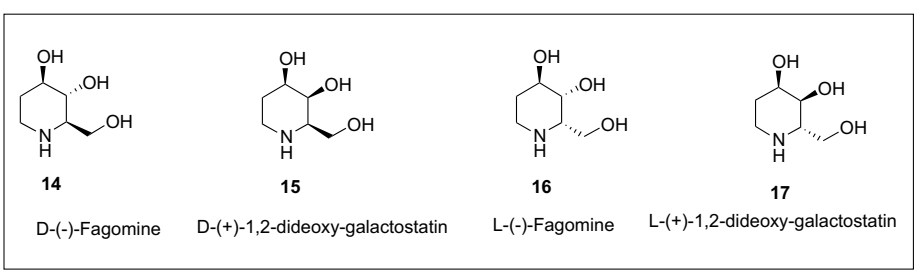

Fig. 7.

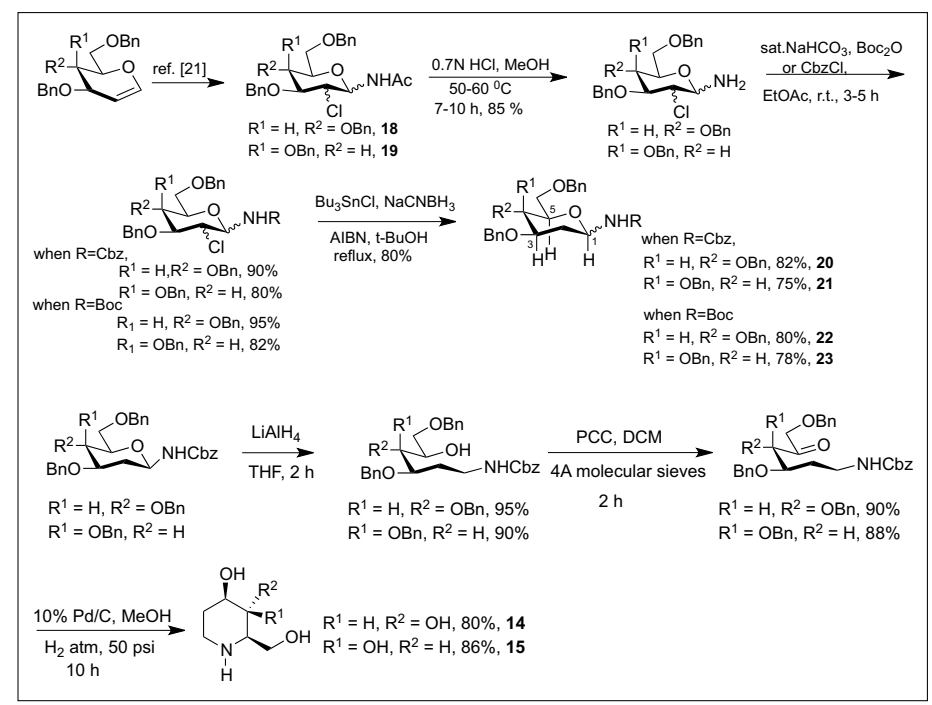

Scheme 15.

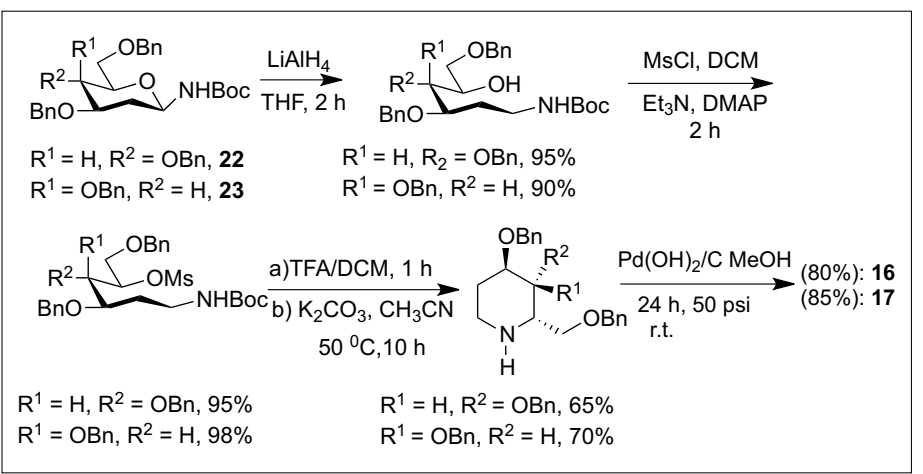

Scheme 16.

\section{Synthesis of Glycosidase Inhibitors}

The above-described methodologies to obtain 2-deoxy amino sugars were further utilized in the synthesis of D- and L-fagomines. This stemmed from our continued interest ${ }^{[23]}$ in the synthesis and biological evaluation of imino (or aza) sugars and carbasugars as potential glycosidase inhibitors. Glycosidase inhibitors are carbohydrate-processing enzymes that are involved in numerous fundamental biological processes. ${ }^{[24]}$ Many nitrogen-containing heterocycles such as nojirimycin, 1-deoxynojirimycin, fagomine, isofagomine etc. are piperidine derivatives as their numerous analogues have been found to inhibit glycosidases. As a result, some of these imino (or aza) sugars are effective therapeutic agents for the treatment of a wide range of diseases including diabetes, viral infection, tumor metastasis, and lysosomal storage disorders. Because of these developments many synthetic approaches towards naturally occurring imino (or aza) sugars and their structural analogues have been reported ${ }^{24]}$ in the literature. In our studies we have utilized[25] the chemistry of 2-deoxy-1-amino sugars obtained from the $\mathrm{Me}_{3} \mathrm{SiONO}_{2} / \mathrm{Me}_{3} \mathrm{SiN}_{3}$ - and oxalyl chloride- $\mathrm{AgNO}_{3}-\mathrm{CH}_{3} \mathrm{CN}$-based methodologies to synthesize D-(-)-fagomine 14, D-(+)-1,2-dideoxy-galactostatin 15, L(-)-fagomine 16, and L-(+)-1,2-dideoxygalactostatin 17 (Fig. 7).

Synthesis of D-(-)-fagomine 14, D(+)-1,2-dideoxy-galactostatin 15 starting from 2,4,6-tri- $O$-benzyl glucal and galactal respectively and via a sequence of reactions is shown in Scheme 15. The key step is the functionalization of glycals with oxalyl chloride- $\mathrm{AgNO}_{3} / \mathrm{CH}_{3} \mathrm{CN}$ to procure the corresponding 2-chloro acetamides
18 and 19 which were further taken to the target iminosugars via dechlorinated products 20 and 21. Further, compounds L-(-)-fagomine 16, and L-(+)-1,2-dideoxy-galactostatin 17 were obtained from $\mathrm{N}$-Boc-protected sugar derivatives 22 and $\mathbf{2 3}$ as shown in Scheme 16.

Likewise, 2,4,6-tri- $O$-benzyl glucal and galactal were converted into D-(-)-fagomine 14, D-(+)-1,2-dideoxy-galactostatin 15 using the reagent system $\mathrm{Me}_{3} \mathrm{SiONO}_{2} /$ $\mathrm{Me}_{3} \mathrm{SiN}_{3}{ }^{[13]}$ developed in our laboratory, to functionalize them to 2-deoxy-1-azidosugars 24 and 2 respectively. These azido compounds were reduced with $\mathrm{LiAlH}_{4}$ to amino alcohols $\mathbf{2 5}$ and $\mathbf{2 6}$ respectively and then further taken to the desired targets 14 and $\mathbf{1 5}$ via a sequence of reactions as shown in Scheme 17.

Further, NH-nosylates $\mathbf{2 7}$ and $\mathbf{2 8}$ were directly cyclized using diisopropyl azadicarboxylate (DIAD) and triphenylphosphine followed by deprotections led to L-(-)-fagomine 16, and L-(+)-1,2-dideoxygalactostatin $\mathbf{1 7}$ as shown in Scheme 18. Since the glycosidase inhibition studies for compounds $\mathbf{1 4}$ and $\mathbf{1 5}$ have already been reported, the inhibitory activity of fagomine isomers $\mathbf{1 6}$ and $\mathbf{1 7}$ were tested against a few glycosidases. Thus, compound 16 was found to show moderate inhibition of $\beta$-glucosidase (almonds, 5.8 $\mathrm{mM}$ ), $\alpha$-galactosidase (coffee beans, 0.6 $\mathrm{mM}$ ) and $\beta$-galactosidase (bovine liver, 


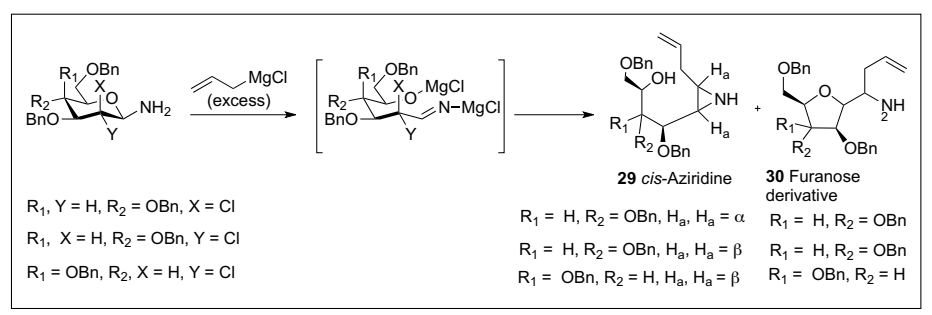

Scheme 19.

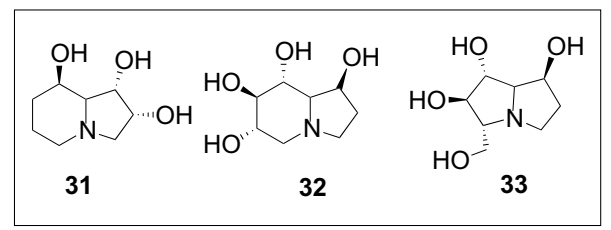

Fig. 8.
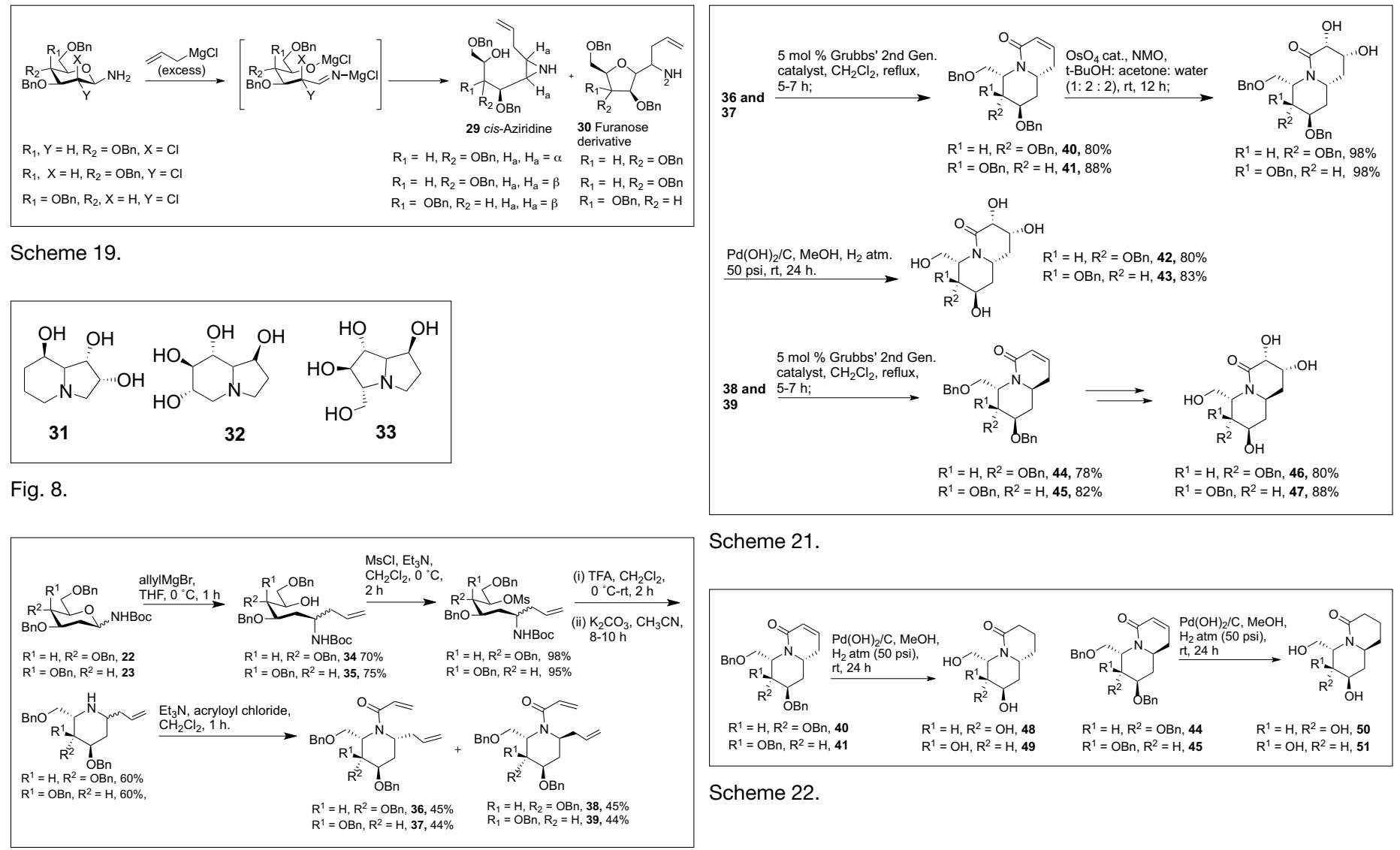

Scheme 21.

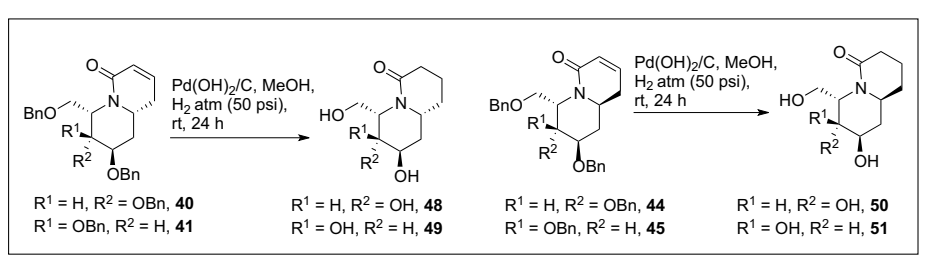

Scheme 22.

Scheme 20.

$0.67 \mathrm{mM}$ ) while it showed no inhibition of $\alpha$-glucosidase (rice), and $\alpha$-mannosidase (jack beans). On the other hand, compound 17 showed no inhibition of $\alpha$-glucosidase, $\beta$-glucosidase and $\alpha$-mannosidase but reasonable inhibition of $\alpha$-glactosidase (coffee beans, $0.9 \mathrm{mM}$ ) and $\beta$-galactosidse (bovine liver, $0.8 \mathrm{mM}$ ). Clearly, it is possible to further make structural modifications to improve inhibitions and selectivity associated with it.

More recently, we have also converted $^{[26]}$ the glycal-derived 2-chloro amines into aziridine $\mathbf{2 9}$ and furanose derivatives 30 as shown in Scheme 19. Further scope of these molecules in terms of converting them into some useful glycosidase inhibitors is being investigated.

Polyhydroxylated indolizidine, pyrrolizidine, and quinolizidine aza-bicyclic alkaloids are useful molecules from the glycosidase inhibition point of view. Among others, swainsonine 31, castanospermine 32 and alexine 33 (Fig. 8), and their derivatives have been well studied from synthesis as well as biological activity point of view. Although there are many reports pertaining to the synthesis of indolizidine and pyrrolizidine derived glycosidase inhibitors, very few reports of polyhydroxylated quinolizidines are known. ${ }^{[27]} \mathrm{We}$ considered the possibility of employing the procedure for amino sugar formation using oxalyl chloride- $\mathrm{AgNO}_{3}-\mathrm{CH}_{3} \mathrm{CN}$ reagent system ${ }^{[21]}$ for the synthesis of eight new quinolizidine molecules and also their assessment in terms of glycosidase inhibition activity. The synthesis from 2,4,6-tri$O$-benzyl glucal and galactal is shown in Scheme 20 employing the methodology developed in our laboratory for functionalizing the glycals to 2-chloro acetamides. [28]

The glucal and galactal derived 1-amino-2-deoxy sugars $\mathbf{2 2}$ and $\mathbf{2 3}$ were reacted with allyl magnesium bromide to form amino alcohols 34 and $\mathbf{3 5}$ respectively which were then carried forward to cyclized dienes 36, 37, 38 and 39 through a series of reactions ( $c f$. Scheme 20). verted into the polyhydroxylated quinolizidines $\mathbf{4 2}$ and $\mathbf{4 3}$ respectively as shown in Scheme 21 using Grubb's second-generation catalyst for ring-closing metathesis followed by dihydroxylation and deprotections. Likewise, compounds $\mathbf{3 8}$ and $\mathbf{3 9}$ gave bicyclic molecules 46 and 47 using similar sequence of reactions.

Further, the bicylic enamides 40, 41, 44 and $\mathbf{4 5}$ were hydrogenated and also debenzylated using $\mathrm{Pd}(\mathrm{OH})_{2} / \mathrm{MeOH} / \mathrm{H}_{2}$ at $50 \mathrm{psi}$ for 24 h to form trihydroxyamides 48,49 , 50 and 51 (Scheme 22) respectively.

The inhibitory activity of all new bicyclic quinolizidinone molecules 42,43 , 46, 47, 48, 49, 50, 51 were tested against a few glycosidases. Thus, pentahydroxylated-quinolizidinones 42,43 and 46 did not show good inhibition while $\mathbf{4 7}$ showed moderate inhibition of $\beta$-glucosidase (al-
The dienes 36 and 37 were then con- monds, $0.75 \mathrm{mM}$ ) and $\beta$-galactosidase (bovine liver, $0.29 \mathrm{mM}$ ). On the other hand, trihydroxyquinolizidines 48, 49, 50 and 51 were found to be selective inhibitors of glycosidases. Thus, compound 48 was found to inhibit $\beta$-galactosidase (bovine liver) at $1.40 \mathrm{mM}$ concentration whereas compound 11b showed inhibition of $\alpha$-mannosidase (jack beans) at 0.37 $\mathrm{mM}$ concentration. Likewise, compound 12a showed inhibition of $\beta$-glucosidase (almonds) at $3.80 \mathrm{mM}$ while compound 12b inhibited $\beta$-galactosidase at $1.58 \mathrm{mM}$ concentrations respectively. Clearly, the selective inhibition using the last four compounds is encouraging and these could be improved by further studies with respect to change in position, stereochemistry and number of $-\mathrm{OH}$ groups/and or ring sizes.

\section{Acetyl Chloride-AgNO $-\mathrm{CH}_{3} \mathrm{CN}-$ mediated Synthesis of 2-Nitro Glycals and 2-Nitro-1-acetamido Sugars}

Finally more recently, we have introduced ${ }^{[29]}$ a new reagent system comprising $\mathrm{CH}_{3} \mathrm{COCl}-\mathrm{AgNO}_{3}-\mathrm{CH}_{3} \mathrm{CN}$ for the conversion of glycals into 2-nitro glycals and also to 2-nitro-1-acetamido sugars. The nature of the product depends upon the reaction conditions. The reactions are believed to proceed as shown in Scheme 23.

The 2-nitroglycals are useful intermediates ${ }^{[30]}$ in carbohydrate chemistry and access to such molecules from glycals under 


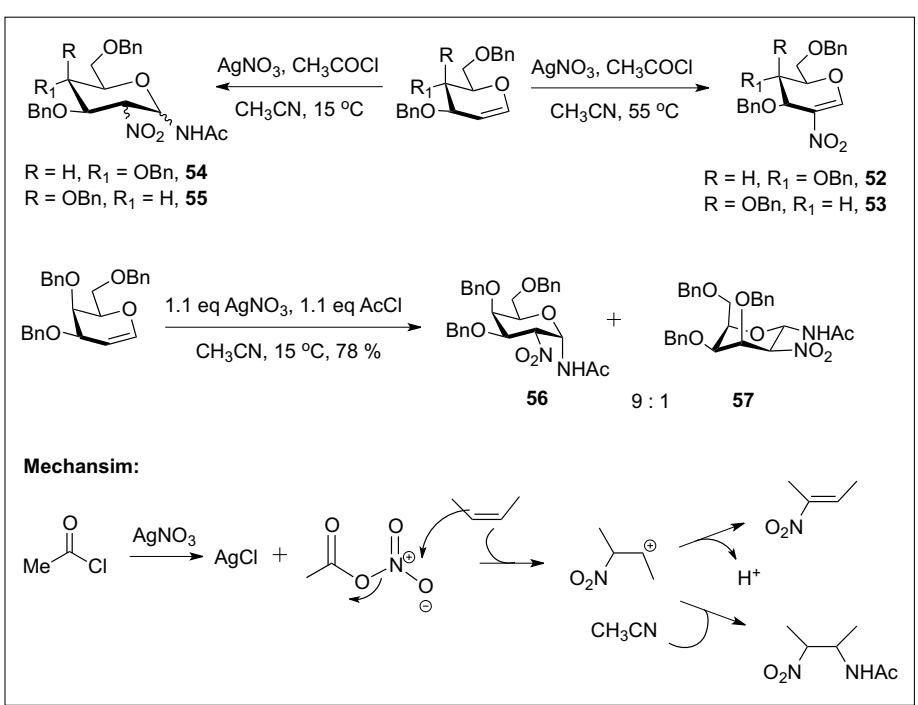

Scheme 23.

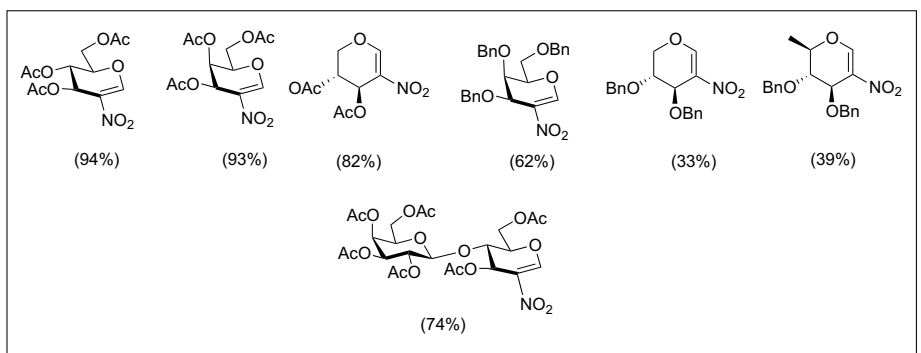

Fig. 9.

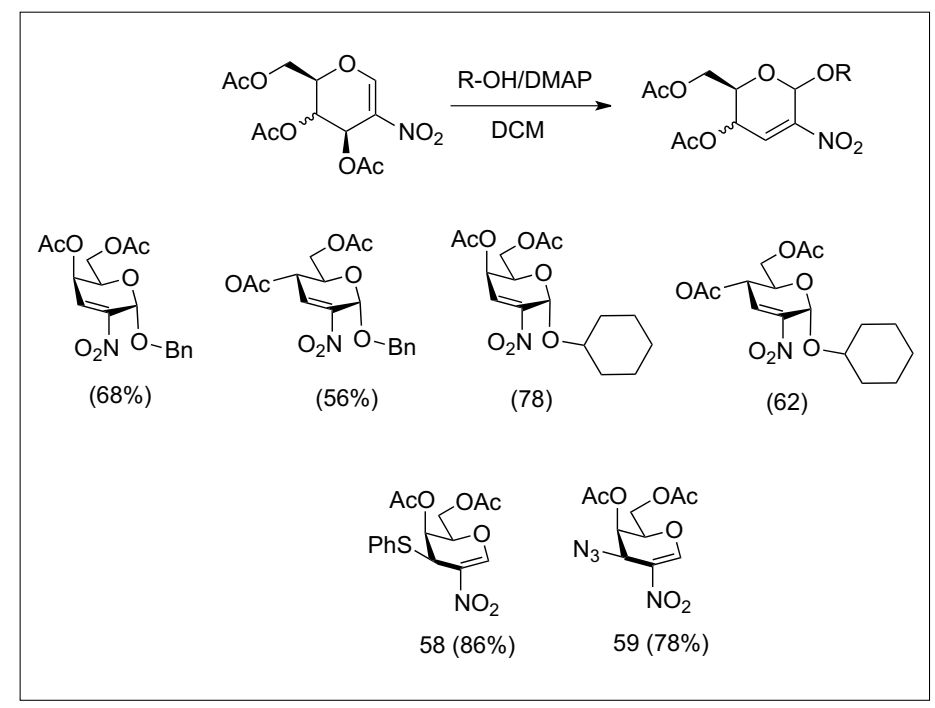

Scheme 24.

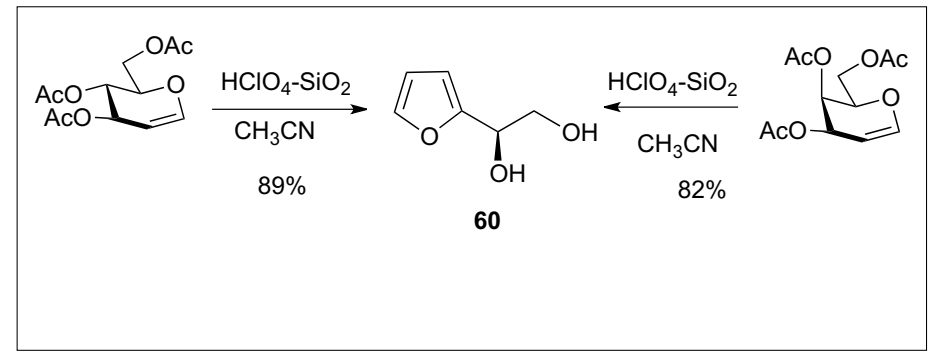

Scheme 25. relatively mild conditions is important. The most commonly used method to procure 2-nitroglycals is from glycals by reacting them with acetyl nitrate (generated from acetic anhydride and nitric acid at $-33{ }^{\circ} \mathrm{C}$ ) followed by treatment with $\mathrm{Et}_{3} \mathrm{~N}$. However, the present method is mild and does not require the use of $\mathrm{Et}_{3} \mathrm{~N}$. Depending on the concentration of $\mathrm{CH}_{3} \mathrm{CN}$ and temperature of the reaction, the product ratio could be managed. Thus, for example, $0.24 \mathrm{mmol}$ of 2,4,6-tri- $O$-benzyl glucal upon treatment with 1 equiv. of $\mathrm{AgNO}_{3}$ and 1 equiv. of $\mathrm{CH}_{3} \mathrm{COCl}$ in $3 \mathrm{~mL}$ of acetonitrile at 55 ${ }^{\circ} \mathrm{C}$ gave 8:1 ratio of 2-nitroglucal $\mathbf{5 2}$ and 2-nitroacetamide 54, as a mixture of diastereomers, in $75 \%$ combined yield. On the other hand, use of $7 \mathrm{~mL}$ of acetonitrile at $15{ }^{\circ} \mathrm{C}$ gave $72 \%$ of the 2-nitroacetamide 54 exclusively. It may be noted that 2-nitrogalactal gave better selectivity of the 2-nitroactamide leading to $78 \%$ of the two products 56 and 57 in 9:1 ratio. A variety of 2-nitroglycals could be procured by this method. A few representative examples of the 2-nitroglycals procured by this method are shown in Fig. 9.

It was interesting to carry out a few reactions $^{[31]}$ on acetylated 2-nitroglycals and it was possible to add alcohols upon catalysis with DMAP to form the corresponding glycosides accompanied by Ferrier type reaction. A few examples are shown Scheme 24. Interestingly, when $\mathrm{PhSh}$ and
$\mathrm{NaN}_{3}$ were used as nucleophiles, the substitution occurred at C(3) forming $\mathbf{5 8}$ and 59 as exclusive products in $86 \%$ and $78 \%$ yields respectively. Further aspects of the chemistry of these newly formed sugarderived nitro-olefins are being carried out and will be reported in due course.

\section{Miscellaneous Transformations of Glycals}

Apart from the above-described transformations, glycals have also been dihydroxylated into 1,2-dihydroxy sugars with oxone-acetone-water- $\mathrm{NaHCO}_{3}$ reagent system in moderate to good yields.[32] Further, we have also found ${ }^{[33]}$ that $\mathrm{HClO}_{4}$ $\mathrm{SiO}_{2}$ reagent system catalyzes addition of a variety of alcohols to 3,4,6-triacetyl glucal to form the corresponding 2,3-unasturated$O$-glucosides via the well known Ferrier reaction $^{[8]}$ in good to excellent yields in short time. Also, 3,4,6-trihydroxy glucal (or galactal) form the chiral furan diol 60 (Scheme 25) in excellent yields when treated with $5 \mathrm{wt} \%$ of $\mathrm{HClO}_{4}-\mathrm{SiO}_{2}$ reagent system.

\section{Conclusions}

In summary, we have been involved in developing a variety of useful transforma- tions of glycals to functionalized sugar substrates and some of them have been utilized in procuring useful glycosidase inhibitors which are either monocyclic or bicyclic imino (or aza) sugars. It is expected that some of these methodologies will find use in organic synthesis and in carbohydrate chemistry in particular.

\section{Acknowledgement}

We thank a number of dedicated coworkers whose names appear in the references for their hard work and excellent experimental contributions and discussions on various aspects of the research projects. One of us (YDV) thanks the Department of Science and Technology, New Delhi [including J. C. Bose National fellowship (JCB/SR/S2/JCB-26/2010)], the Council of Scientific and Industrial Research, New Delhi, and the Indian Institute of Technology Kanpur for continued financial support. RL and SD thank the Council of Scientific and Industrial Research, New Delhi, for Senior Research Fellowships.

Received: October 7, 2012

[1] a) S. J. Danishefsky, M. T. Bilodeau, Angew. Chem., Int. Ed. 1996, 35, 1380; b) R. J. Ferrier, J. O. Hoberg, Adv. Carbohydr. Chem. Biochem. 2003, 58, 55; c) T. Linker, D. Schanzenbach, E. Elamparuthi, T. Sommermann, W. Fudickar, V. Gyollai, L. Somsak, W. Demuth, M. Schmittel, J. Am. Chem. Soc. 2008, 130, 16003; d) E. Kumaran, M. Santhi, K.K. Balasubramanian, S. Bhagavathy, Carbohydr. Res. 2011, 346, 1654; e) R. U. Lemieux, R. M. Ratcliffe, Can. J. Chem. 1979, 57, 1244; f) M. Bols, 
'Carbohydrate Building Blocks', John-Wiley \& Sons, Inc., New York, 1996.

[2] a) S. P. Vincent, M. D. Burkart, C-Y. Tsai, Z. Zhang, C-H. Wong, J. Org. Chem. 1999, 64, 5264; b) J. Liu, V. D. Bussolo, D. Y. Gin, Tetrahedron Lett. 2003, 44, 4015; c) J. M. Owens, B. K. S. Yeung, D. C. Hill, P. A. Petillo, J. Org. Chem. 2001, 66, 1484; d) Y. Ito, T. Ogawa, Tetrahedron Lett. 1987, 28, 2723; e) D. Hou, T. L. Lowray, Carbohydr. Res. 2009, 344. 1911; f) F-M. Gautier, F. Djdaïni, C. Grandjean, Carbohydr. Res. 2011, 346, 577; g) T. B. Durham, W. R. Roush Org. Lett. 2003, 5, 1871.

[3] a) F. W. D'Souza, P. E. Cheshev, J. D. Ayers, T. D. Lowary, J. Org. Chem. 1998, 63, 9037; b) G. J. Mercer, J. Yang, M. J. McKay, H. M. Nguyen, J. Am. Chem. Soc. 2008, 130, 11210; c) R. Lorpitthaya, S. B. Suryawanshi, S. Wang, K. K. Pasunooti, S. Cai, J. Ma, X-W. Liu, Angew. Chem., Int. Ed. 2011, 50, 12054; d) T. B. Durham, W. R. Roush, Org. Lett. 2003, 5, 1875.

[4] a) S. N. Suryawanshi, T. S. Dhami, D. S. Bhakuni, Tetrahedron Lett. 1991, 32, 1519; b) I. F. Pelyvás, J. Thiem, Z. G. Tóth, J. Carbohydr. Chem. 1998, 17, 1; c) L. V. R. Reddy, P. V. Reddy, A. K. Shaw, Tetrahedron:Asymm. 2007, 18, 542; d) M. Yu, V. Lynch, B. L. Pagenkopf, Org. Lett. 2001, 3, 2563; e) F. E. McDonald, Angew. Chem., Int. Ed. 2001, 40, 3653; f) K. M. Engstrom, M. R. Mendoza, M. NavarroVillalobos, D. Y. Gin, Angew. Chem. Int. Ed. 2001, 40, 1128.

[5] M. V. R. Reddy, B. Mehrotra, Y. D. Vankar, Tetrahedron Lett. 1995, 36, 4861.

[6] a) G. Arsequell, G. Valencia, Tetrahedron:Asymm. 1999, 10, 3045; b) R. Okamoto, Y. Kajihara Trends in Glycosci. \& Glycotech. 2008, 20, 203.

[7] K. Pachamuthu, Y. D. Vankar, J. Org. Chem. 2001, 66, 7511 .

[8] R. J. Ferrier, O. A. Zubkov, Org. React. 2003, 62,569 .

[9] W. R. Roush, R. A. James, Aust. J. Chem. 2002, 55,141 .

[10] J. Robichaud, F. Tremblay, Org. Lett. 2006, 8, 597.
[11] A. Cirla, A. R. McHale, J. Mann, Tetrahedron 2004, 60, 4019

[12] M. V. R. Reddy, R. Kumareswaran, Y. D. Vankar, Tetrahedron Lett. 1995, 36, 7149.

[13] B. G. Reddy, K. P. Madhusudanan, Y. D. Vankar, J. Org. Chem. 2004, 69, 2630.

[14] a) Z. Györgydeák, L. Szilágyl, H. Pausen, J. Carbohydr. Chem. 1993, 12, 139; b) Z. Györgydeák, J. Thiem Carbohydr. Res. 1995, 268, 85; c) L. Ying, J. Gervay-Hague, Carbohydr. Res. 2003, 338, 835.

[15] H. Suga, O. Ersoy, T. Tsumuraya, J. Lee, A. J. Sinskey, S. Masamune, J. Am. Chem. Soc. 1994, 116, 487.

[16] B. G. Reddy, Y. D. Vankar, ARKIVOC 2004, viii, 12.

[17] G. K. Rawal, S. Rani, K. P. Madhusudanan, Y. D. Vankar, Synthesis 2007, 294.

[18] a) R. S. Babu, M. Zhou, M., G. A. O'Doherty, J. Am. Chem. Soc. 2004, 126, 3428; b) M. Saeed, T. Ilg, M. Schick, M. Abbas, W. Voelter, Tetrahedron Lett. 2001, 42, 7401; c) J. M. Harris, M. D. Keranen, H. Nguyen, V. G. Young, G. A. O'Doherty, Carbohydr. Res. 2000, 328, 17.

[19] B. G. Reddy, Y. D. Vankar, Tetrahedron Lett. 2003, 44, 4765 .

[20] E. de Guchteneere, D. Fattori, P. Vogel, Tetrahedron 1992, 48, 10603.

[21] G. K. Rawal, A. Kumar, U. Tawar, Y. D. Vankar, Org. Lett. 2007, 9, 5171.

[22] P. A. Colinas, R. D. Bravo, Org. Lett. 2003, 5, 4509 .

[23] a) S. Rani, A. Agarwal, Y. D. Vankar, Tetrahedron Lett. 2003, 44, 5001; b) B. G. Reddy, Y. D. Vankar Angew. Chem., Int. Ed. 2005, 44, 2001; c) V. R. Doddi, Y. D. Vankar, Eur. J. Org. Chem. 2007, 5583; d) A. Kumar, G. K. Rawal, Y. D. Vankar, Tetrahedron 2008, 64, 2379; e) M.A. Alam, Y. D. Vankar, Tetrahedron Lett. 2008, 49, 5534; f) M. A. Alam, A. Kumar, Y. D. Vankar, Eur. J. Org. Chem. 2008, 4972; g) V. R. Doddi, H. P. Kokatla, A. P. J. Pal, R. K. Basak, Y. D. Vankar, Eur. J. Org. Chem. 2008, 5731; h) V. R. Doddi, P. K. Kancharla, Y. S. Reddy, A. Kumar, Y. D. Vankar, Carbohydr Res. 2009, 344, 606; i) A. P. J. Pal, Y. D. Vankar,
Tetrahedron Lett. 2010, 51, 2519; j) A. Kumar, M. A. Alam, S. Rani, Y. D. Vankar, Carbohydr. Res. 2010, 345, 1142; k) A. P. J. Pal, P. Gupta, Y. S. Reddy, Y. D. Vankar, Eur. J. Org. Chem. 2010, 6957; 1) P. Gupta, S. Dharuman, Y. D. Vankar, Tetrahedron:Asymm. 2010, 21, 2966; m) A. P. J. Pal, P. Kadigachalam, A. Mallick, V. R. Doddi, Y. D. Vankar, Org. Biomol. Chem. 2011, 9, 808; n) P. Gupta, A. P. J. Pal, Y. S. Reddy, Y. D. Vankar, Eur. J. Org. Chem. 2011, 1166; o) R. Lahiri, H. P. Kokatla, Y. D. Vankar, Tetrahedron Lett. 2011, 52, 781; p) Y. S. Reddy, A. P. J. Pal, P. Gupta, A. A. Ansari, Y. D. Vankar, J. Org. Chem. 2011, 76, 5972; q) Y. S. Reddy, P. K. Kancharla, R. Roy, Y. D. Vankar, Org. Biomol. Chem. 2012, 10, 2760.

[24] a) T. D. Heightmann, A. T. Vasella, Angew. Chem., Int. Ed. 1999, 38, 750; b) V. H. Lillelund, H. H. Jensen, X. F. Liang, M. Bols, Chem Revs. 2002, 102, 515; c) N. Asano, Glycobiology 2003, 13, 93R; d) T. Kajimoto, M. Node, Curr. Top. Med. Chem. 2009, 9, 13; e) G. Horne, F. $\mathrm{X}$. Wilson, J. Tinsley, D. H. Williams, R. Storer, Drug Discovery Today 2011, 16, 107; f) I. Dragutan, V. Dragutan, A. Demonceau, RSC Advances 2012, 2, 719 .

[25] N. Kumari, B. G. Reddy, Y. D. Vankar, Eur. J. Org. Chem. 2009, 160

[26] R. Lahiri, Y. D. Vankar, unpublished observations.

[27] a) H. Hamana, N. Ikota, B. Ganem, J. Org Chem. 1987, 52, 5492; b) P. S. Liu, J. Org. Chem. 1987, 52, 4717; c) C. Schaller, P. Vogel, Helv. Chim. Acta. 2000, 83, 193.

[28] N. Kumari, Y. D. Vankar, Org. Biomol. Chem. 2009, 7, 2104.

[29] P. K. Kancharla, Y. S. Reddy, S. Dharuman, Y. D. Vankar, J. Org. Chem. 2010, 76, 5832.

[30] a) R. R. Schmidt, Y. D. Vankar, Acc. Chem. Res. 2008, 41, 1059; b) P. K. Kancharla, Y. D. Vankar, J. Org. Chem. 2010, 76, 8457; c) S. Vedachalam, S. M. Tan, H. P. Teo, S. T. Cai, X-W. Liu, Org. Lett. 2012, 14, 174.

[31] S. Dharuman, Y. D. Vankar, unpublished observations.

[32] S. Rani, Y. D. Vankar, Tetrahedron Lett. 2003, 44, 907.

[33] A. Agarwal, S. Rani, Y. D. Vankar, J. Org. Chem. 2004, 69, 6137. 